\title{
地域の課題とニーズに基づくロンドンの区立図書館「Idea Store」

\author{
RELATIONS BETWEEN URBAN PLANNING AND REORGANIZATION OF \\ PUBLIC LIBRARY 'IDEA STORE' IN LONDON, \\ CORRESPONDING TO THE LOCAL PROBLEMS AND NEEDS
}

\author{
李燕*, 小松 尚** \\ Yan LI and Hisashi KOMATSU
}

\begin{abstract}
London Borough of Tower Hamlets has successfully renewed local public libraries as Idea Stores. This research focuses on UK library policies, London spatial plan and Tower Hamlets's community plan, and aims to make clear of progress of reorganization of public library in Tower Hamlets, which corresponds to the local problems and needs.

It turns out that Tower Hamlets Council relocated the libraries according to the London Plan and local development framework. Besides, it expands library service based on Central Government's library polices as well as Tower Hamlets Community Plan. These policies, especially local government's plan, provide important context for refreshing Tower Hamlets's libraries.
\end{abstract}

keywords: Public Library, Facility Reorganization, London Plan, Community Planning 公共図書館, 施設再編, ロンドン・プラン, 地域計画

\section{1. 研究概要}

\section{1-1. 背景}

これからの公共施設整備においては、人口減少や少子高齢化の進 化による社会構造の変化に即した施設配置と建築空間の整備及びプ ログラムの開発が必要になろう。そのような視点から現在の日本の 公共図書館を見ると、滞在型図書館が増加し、また地域の「知の基 盤」として市街地再開発やまちづくりの拠点のひとつになっている 事例が各地で確認できる。しかし、これまでのところ、単館の整備 に留まり、複数の公共図書館を総合的に再編した事例は少ない。

一方で、2012 年に文部科学省は新しい「図書館の設置及び運営 上の望ましい基準」を公表し、公共図書館サービスとして「地域の 課題に対応したサービス」を新しく追加し、利用者と住民の生活や 仕事に関する課題や地域の課題の解決に向けた活動を支援する必要 性を示した。しかし、この基準に含まれるサービスは、上記の活動 支援に関する資料と情報の提供が中心である。つまり、これからの 公共図書館再編に向けた施設の配置や建築空間の整備方法、プログ ラム開発はまだ検討段階であり、政策上もその方向性を明確に示す ものは少ないと考えられる注1)。

地域の課題とニーズに応える形で公共図書館の今日的な役割を体 現するための図書館再編が行われている海外事例に着目すると、イ ギリス・ロンドン東部のタワー・ハムレッツ区 (London Borough of Tower Hamlets、以下 TH 区) は地域再生を目標とした都市計画 及び地域計画と連動しながら、複数の区立図書館の配置と建築空
表 1 IS およびTH 区立図書館の概要

\begin{tabular}{|c|c|c|c|c|c|}
\hline 図書館 & 開館年 & 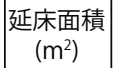 & \begin{tabular}{|l|} 
蔵書数(点) \\
(2012.3現在)
\end{tabular} & \begin{tabular}{|c|} 
年間貸出数 \\
(2012年度)
\end{tabular} & $\begin{array}{l}\text { 年間訪問者数 } \\
\text { (2013年度)注2 }\end{array}$ \\
\hline \begin{tabular}{|l} 
Idea Store \\
Bow (ISB) \\
\end{tabular} & 2002(改築) & 1,350 & 42,273 & 131,748 & 286,958 \\
\hline \begin{tabular}{|l|} 
Idea Store \\
Chrisp Street (ISCS) \\
\end{tabular} & 2004 (改築) & 1,240 & 695 & 157,366 & 431,600 \\
\hline \begin{tabular}{|l} 
Idea Store \\
Whitechapel (ISW)
\end{tabular} & 2005 (新築) & 3,700 & 82,380 & 253,813 & 689,381 \\
\hline $\begin{array}{l}\text { Idea Store } \\
\text { Canary Wharf (ISCW) }\end{array}$ & 2006 (新築) & 940 & 33,927 & 124,985 & 298,055 \\
\hline \begin{tabular}{|l|} 
Idea Store \\
Watney Market (ISWM) \\
\end{tabular} & 2013 (新築) & 1,270 & 21,463 & 87,896 & 319,652 \\
\hline $\begin{array}{l}\text { Bethanl Green Library } \\
\text { (BGL) }\end{array}$ & (既存図書館) & 不明 & 42,980 & 96,224 & 147,184 \\
\hline $\begin{array}{l}\text { Cubit Town Libray } \\
\text { (CTL) }\end{array}$ & (既存図書館) & 不明 & 24,784 & 66,106 & 75,422 \\
\hline
\end{tabular}

注1: ISWMについてはその前身であるWatney Market Librayのデータ。 注2: ISWMについては開館した5月以降のデータ。

間、そして提供プログラムを TH 区の課題とニーズに対応して再編 し、成果を収めている 1),2),3),4),5)。都市や地域に関する上位計画と 公共図書館の建築空間及び提供プログラムを連動させながら実現し た TH 区立図書館の再編経緯を分析することにより、今後の日本の 公共図書館においても必要になる地域の課題とニーズに基づく公共 図書館の再編に関する知見を得ることができると思われる。

1-2. 研究目的と方法

そこで本稿では、TH 区において 2002 年から順次開館した 5 館 の区立図書館 (通称 Idea Store、以下 IS)(表 1) を対象に、ロンドン 及び TH 区の都市・地域計画及び関連政策と IS の整備過程、特に TH 区域における IS の配置との関係を明らかにすることを目的とす 
る。

研究方法としては、3 章でイギリスの公共図書館の整備状況と IS の建築空間及び提供プログラムを確認した後、まずイギリスの公共 図書館に関する政策 (4.5 章) 及び健康に関する公共サービス (6 章) と IS の整備内容の関係を分析する。次にロンドン及び TH 区の都 市・地域計画と IS の配置に関する状況および計画の関係を分析し、 $4 \sim 6$ 章の分析結果を加味しながら、関連政策と IS の整備内容の 相互関係を総合的に分析し、考察する (7 章)。

なお、IS の立地と建築空間、提供プログラムの特性及びその相 互関係の解明は重要な研究課題であるが、それぞれは IS の政策的 な位置付けと深く関係するため、本稿での研究成果を基にして別稿 で改めて論考する。

\section{1-3. 調査方法}

(1)公表された IS に関する文献の調査と、2013 年 9 月と 2014 年 2

月、 5 月に実施した現地調査を通じて、各 IS の立地状況と建築 空間に関する整備内容と提供プログラムを把握した。

(2) 2014 年 2 月に実施した IS の代表補佐へのヒアリングと受領し た資料から、これまでの IS の成果と今後の課題を把握した。

(3)イギリスの公共図書館計画やロンドン及び TH 区の都市・地域計 画に関する各政策の内容と関連性を、公表されている文献等から 把握した。

\section{2. 既往研究と本研究の位置づけ}

イギリスの公共図書館政策に関しては、須賀が公共図書館の運営 や管理における中央政府と地方政府の役割について論じている ${ }^{6)}$ しかし、その研究は公共図書館・博物館法が成立された 1965 年か ら 2009 年までの中央と地方の行政制度の変化について論じている のに留まっており、本稿で分析する 90 年代から現在までの個々の 図書館政策の内容については、あまり詳しく論じられていない。

IS については、図書館学分野において事例報告と書籍が幾つか 確認できる 1),2),3),4)。しかし、TH 区立図書館を IS として再編する に至った経緯やその再編プロセスに関する建築学分野の研究成果は ほとんど確認できない。

\section{3. イギリスの公共図書館と IS の概要}

\section{3-1. イギリスの公共図書館の整備と利用状況}

表 2 は 2012 年におけるイギリスと日本の公共図書館の整備状 況を比較したものである。イギリスにおいて公共図書館を設置でき る自治体の平均人口は日本より多いが、日本の 1 自治体 (市町村) あたりの公共図書館数が 2.4 館であるのに対して、イギリスの 1 自治体の公共図書館数は 19.9 館となっている。

また、イギリスと日本の公共図書館の利用状況を比較して見ると (表 3)、日本の 1 人あたりの貸出数はイギリスより多いが、1 人あ たりの公共図書館の来訪回数はイギリスより少ない。つまり、日本 の公共図書館における貸出利用は多いものの、必ずしも多くの市民 が公共図書館に来訪し、利用しているとは言えない。一方で、イギ リスの公共図書館の利用も年々減少しているが、これはインター ネットや電子媒体による情報取得の影響以外に、イギリス政府の公 共図書館に対する予算削減が大きく影響していると考えられる。こ の課題に対して、イギリスでは公共図書館サービスを守ろうとする
表 2 イギリスと日本の公共図書館の整備状況

\begin{tabular}{|c|c|c|c|}
\hline & \multirow{2}{*}{$\begin{array}{l}\text { イギリス } \\
\text { (UK) 注1 }\end{array}$} & \multicolumn{2}{|c|}{ 日本注2 } \\
\hline & & 都道府県 & 市町村 \\
\hline 人口(千人)注3 & 64,106 & 126,660 & 126,660 \\
\hline 公共図書館を設置できる自治体数 & 211 & 47 & 1,742 \\
\hline 公共図書館を設置した自治体数 & 211 & 47 & 1,306 \\
\hline 公共図書館設置率 & $100 \%$ & $100 \%$ & $75 \%$ \\
\hline $\begin{array}{l}\text { 公共図書館を設置できる } \\
\text { 自治体の平均人人) }\end{array}$ & 303.8 & $2,694.8$ & 72.7 \\
\hline 公共図書館数(館)注4 & 4,194 & 60 & 3,168 \\
\hline 1 館あたり人口(千人) & 15.3 & 2,111 & 39.9 \\
\hline $\begin{array}{l}\text { 公共図書館を設置した } \\
\text { 1自治体あたり書館数(館) }\end{array}$ & 19.9 & 1.3 & 2.4 \\
\hline
\end{tabular}

注1: イギリスのCIPFA (Chartered Institute of Public Finance and Accountancy)が公 表したCIPFA Library Surveyを参照7。

注2: 日本図書館協会が発行した「日本の図書館一統計と名簿2013」8)を参照。

注3: 日本の人口は「全国市町村要覧[平成24年度]」(第一法規) ${ }^{9}$ を参照。イギリス の人口は2014年6月26日に公表された「Population Estimates for UK, England and Wales, Scotland and Northern Ireland - Mid-2013」を参照10)。 注 4 : イギリスの公共図書館数には開館時間が週10時間以下の図書館は含まない。

表 3 イギリスと日本の公共図書館の利用状況 (2012 年度)

\begin{tabular}{|l|c|c|}
\hline & イギリス注 & 日本注 \\
\hline 人口(千人)注3 & 64,106 & 127,515 \\
\hline 公共図書館数(館)注 4 & 4,194 & 3,228 \\
\hline 蔵書冊数(千冊) & 92,181 & 415,814 \\
\hline 貸出冊数(千点) & 265,198 & 711,370 \\
\hline 公共図書館来訪者数(千人)注5 & 288,044 & 309,867 \\
\hline 1人あたりの蔵書冊数(点/人) & 1.44 & 3.26 \\
\hline 1人あたりの貸出数(点/人) & 4.14 & 5.58 \\
\hline 1人あたりの来訪回数 & 4.49 & 2.43 \\
\hline
\end{tabular}

注1：イギリスのCIPFA (Chartered Institute of Public Finance and Accountancy)が 公表したCIPFA Library Surveyを参照した。

注2：日本図書館協会が発行した「日本の図書館一統計と名簿2013」8)を参照。

注3：日本の人口は、国勢調査人口データである。イギリスの人口はNational

Statistics 「Population Estimates for UK, England and Wales, Scotland and Northern Ireland - Mid-2011 and Mid-2012」を参照 ${ }^{11)}$ 。

注 4 ：イギリスの公共図書館数には開館時間が週10時間以下の図書館は含まない。 注5：公共図書館への来訪者の延べ人数。

動きが起き、各自治体も市民の図書館利用の促進に向けて積極的に 努力している。

本稿で分析する TH 区は、90 年代にロンドン特別区 (London Borough) の中で図書館利用率が最も低い特別区の 1 つであった。 しかし、地域の課題とニーズに対応して TH 区立図書館を再編した 結果、5 つの IS の内の旗艦的図書館である ISW の 2013 年度の年 間来訪者数は、イギリスの全公共図書館の中で 8 位になった注 2)。

\section{3-2. IS の開館に至る経緯}

TH 区は人口が 26 万人を超えるが、そのうちの半分を移民が占 め、低所得者が多いなど、ロンドンの中で最も貧しい地域の 1 つで ある。多くの移民は英語の読み書きができず、また高等教育を受け ていない。そのため、90 年代に英語の図書を主に扱った区内の 13 館の区立図書館は、移民によってほとんど使われていなかった。ま た、1998 年に市民による公共図書館の平均利用率がイギリス全体

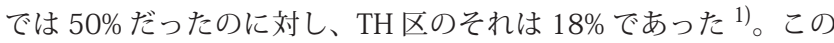
課題に対して、TH 区は 1 年をかけて区立図書館利用に関する住民 意向調査を実施し、その結果に基づいて住民が求める公共図書館の あり方を検討した。そして、3-3 で述べる戦略に基づいて TH 区立 
表 4 2013-14 年度の IS の学習テーマとコース

\begin{tabular}{|c|c|c|c|c|c|c|c|c|c|c|c|c|c|c|c|}
\hline $\bar{\tau}-\nabla$ & \multicolumn{2}{|c|}{ 就業支援 } & \multicolumn{2}{|c|}{ 健康支援 } & 子育て支援 & \multicolumn{10}{|c|}{ 趣味・生涯学習 } \\
\hline ヨ-ス & $\begin{array}{l}\mid \text { 生活·仕事 } \\
\text { ための準備 }\end{array}$ & $\begin{array}{l}\text { 有資格 } \\
\text { コ一 }\end{array}$ & フィットネス & 健康\&福祉 & 家族学習 & $\begin{array}{c}\text { ビジネス } \\
\text { 金融 }\end{array}$ & $\begin{array}{c}\text { קァッション } \\
\text { 織物 }\end{array}$ & $\begin{array}{c}\text { 外国語 } \\
\text { 翻訳 }\end{array}$ & 料理 & 健康福祉 & IT技術 & 公演芸術 & 撮影術 & 技術教育 & 視覚芸術 \\
\hline ISB & & & 0 & & & 0 & 0 & & & & & & 0 & 0 & O \\
\hline ISCS & O & & & 0 & 0 & & O & 0 & 0 & & 0 & & 0 & 0 & 0 \\
\hline ISW & 0 & 0 & 0 & 0 & 0 & 0 & 0 & 0 & 0 & 0 & 0 & 0 & 0 & 0 & \\
\hline ISCW & 0 & & & & & O & $\mathrm{O}$ & & & & & & 0 & & $\mathrm{O}$ \\
\hline BGL & & & & & & & O & & & & & & & & \\
\hline SHC & 0 & 0 & 0 & 0 & 0 & 0 & 0 & 0 & 0 & 0 & 0 & 0 & 0 & 0 & 0 \\
\hline
\end{tabular}

図書館を再編し、IS として開館することを決定した。

\section{3-3. IS の戦略}

TH 区は 1999 年に IS の開設に向けた最初の戦略書である「A Library and Lifelong Learning Development Strategy for Tower Hamlets」 ${ }^{12)}$ (以下、IS 戦略 1999) を発表した。これは、区立図書 館の再配置計画や、生涯学習プログラムの導大など、新しい公共図 書館の空間と提供プログラムを整備するための具体的な方策を示す ものであった。

さらに、2009 年には IS の 10 年間の成果に基づいて次の 10 年 を展望する「Idea Store Strategy 2009」13)(以下、IS 戦略 2009) を発表した。ここでは、IS が提供する学習プログラムを個人の生 涯学習支援に加えて、TH 区の地域課題である就業・健康支援にも 対応する方針を示した。

\section{3-4.IS の特徵}

TH 区は区立図書館の低い利用率の改善と地域の就業・雇用支援 を実施するために、以下の点から区立図書館を再編した。

\section{3-4-1.TH 区立図書館の再配置計画}

1990 年代における TH 区の一人あたりの区立図書館数はロンド ン特別区の中で最も高かったが、前述のように利用率はとても低く、 加えて多くの図書館は住民がアクセスしにくい場所に立地してい た。図書館の数より立地に問題があると判断した TH 区は注 3)、住 民が徒歩で 20 分以内に到着できることを前提に、13 の TH 区立図 書館を最終的に 7 館に集約する再編計画を策定した。現在、TH 区 には 5 つの IS と 2 つの既存図書館が開館している (図 1)。

\section{3-4-2. 多様な学習コースの提供}

TH 区は、英語の読み書きができない移民や高等教育を受けてい ない住民に対する学習支援を実施するにあたって、区立図書館と成 人学習センターが潜在的に利用者を共有していることから、両者の 連携をはかることによって相乗効果が期待できると判断した。現 在、IS では従来の公共図書館機能である図書の収蔵と閲覧、貸出、 学習などだけではなく、TH 区の成人学習センターの 1 つである Shadwell Centre(以下 SHC) と連携しながら、IS でもファッション や料理、ダンスなどの生涯学習コースが提供されている。最近では、 住民の就業と健康支援にも対応するために、雇用に必要な外国語や コンピューター技術の習得、健康を維持するためのフィットネスな どの学習コースも提供されている (表 4)。

\section{3-4-3. 建築デザイン上の配慮}

新しく開館した IS は商店街や屋外マーケットと近く、加えて公 共交通によりアクセスしやすい場所に立地している。また、伝統的

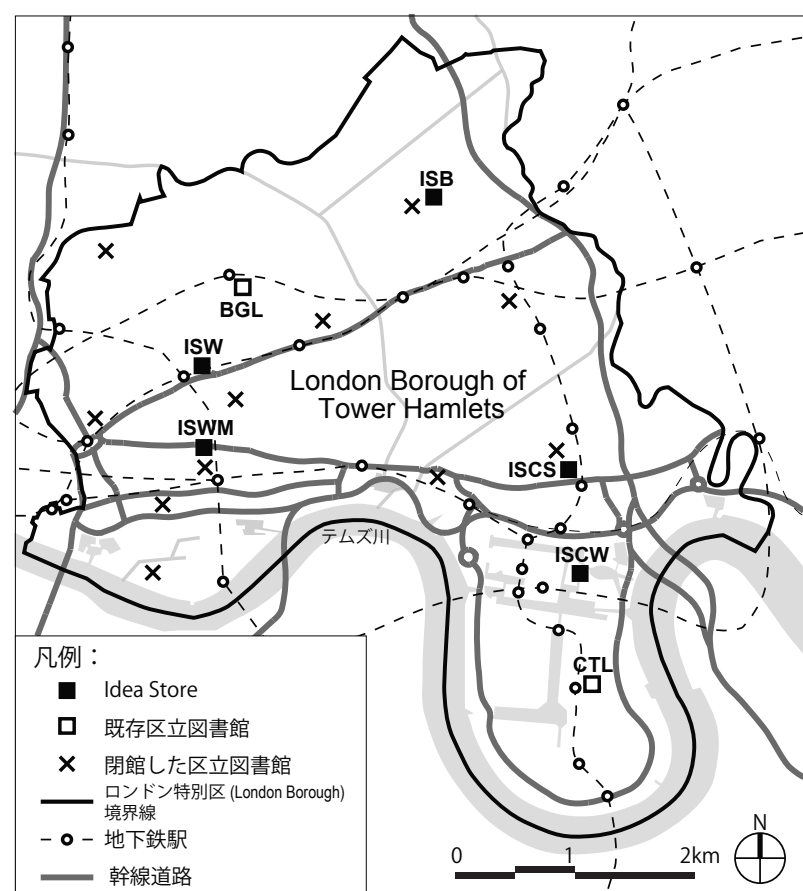

\section{図 1 TH 区立図書館の配置}
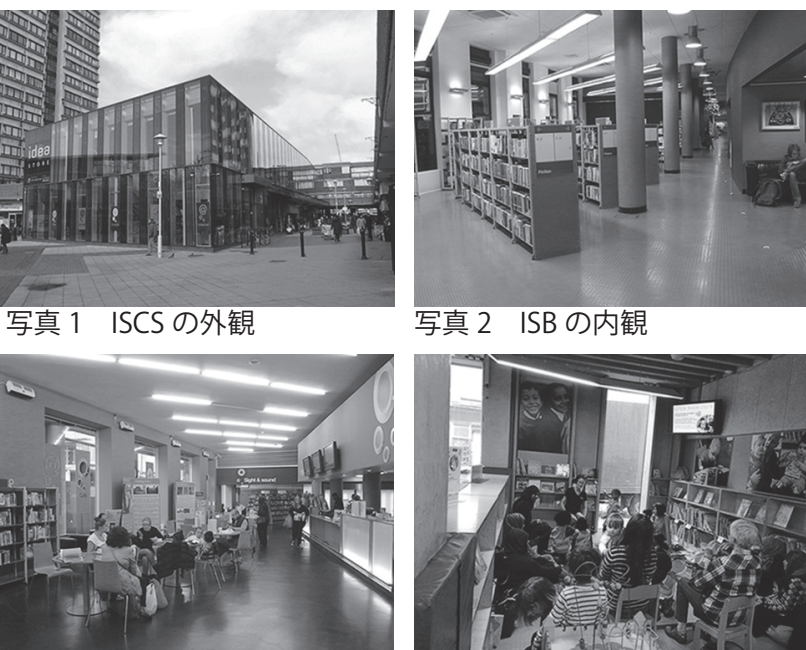

写真 2 ISB の内観

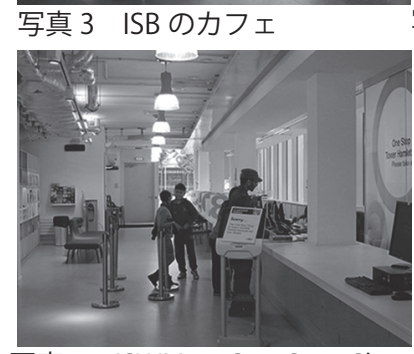

写真 5 ISWM の One Stop Shop

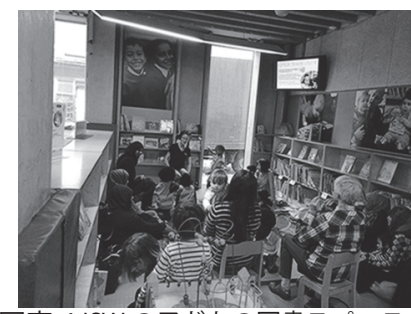

写真 4 ISW の子どもの図書スペース

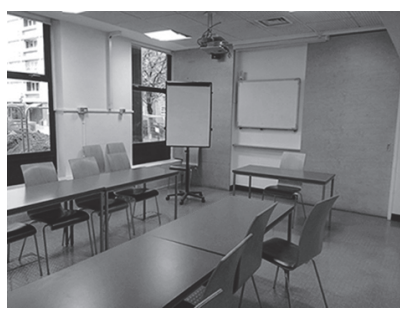

写真 6 ISB の学習教室 


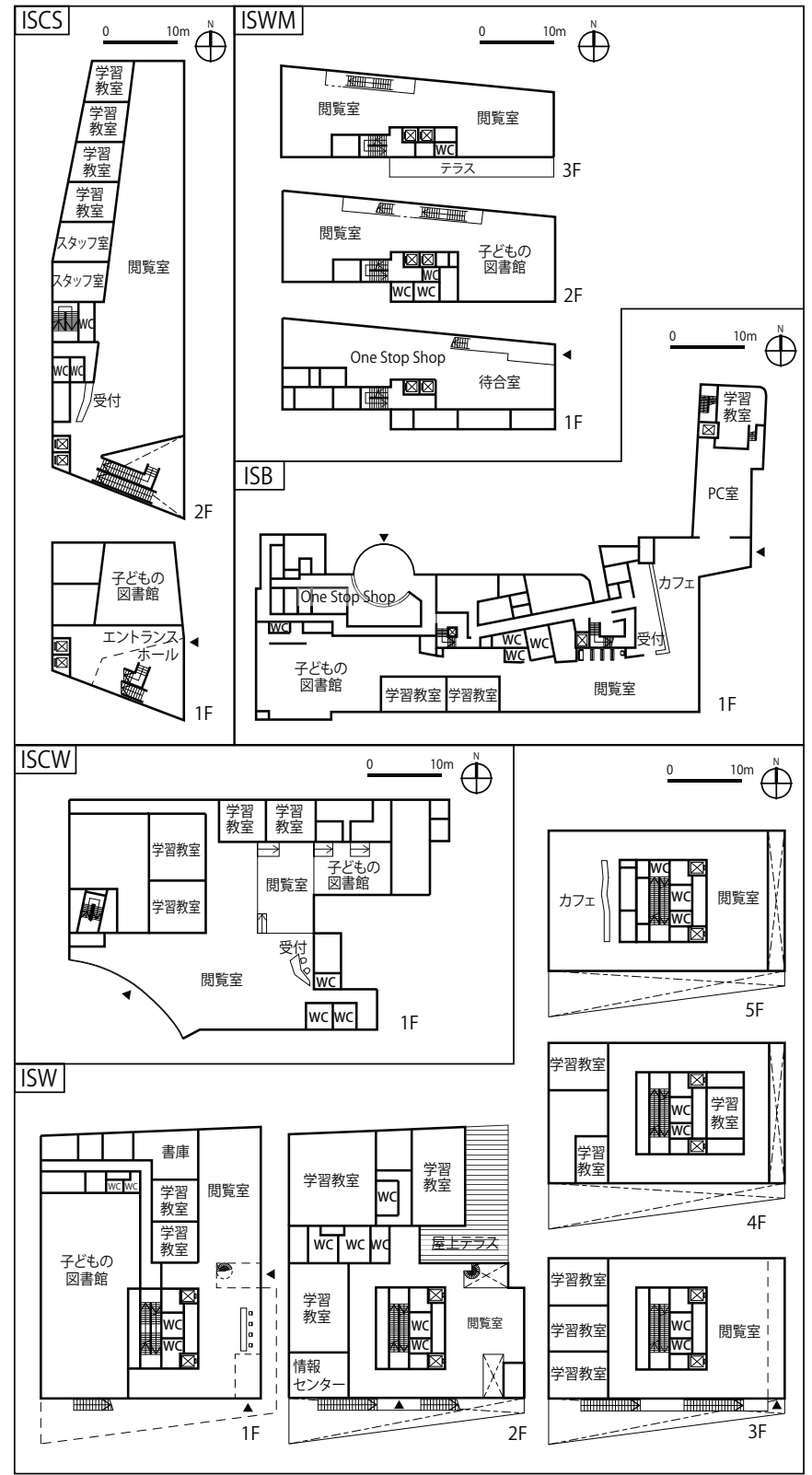

図 2 IS の平面図

なイギリスの公共図書館建築とは異なり、ガラス張りの外壁や鮮や かな色を使ったインテリア・デザインにより、外部からの視認性を 高め、図書館の入口付近にカフェを設けるなど、読書を目的としな

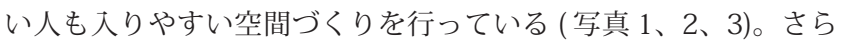
に、書架が並ぶ読書スペースだけではなく、学習コースを行う教室 やPC 室、子どものためのスペース、行政サービスを提供する空口 (One Stop Shop) も設置している (写真 4、5、6、図 2)。

\section{3-5.IS の成果}

2011 年度における TH 区全体の公共図書館訪問者数 (TH 区歴史 資料館を含む ) は、IS 開館前の 2001 年に比べ $240 \%$ 増加し、貸出 数 (オンライン図書館、成人学習センターの貸出数も含む) は $28 \%$ 増加した (図 3)。IS 戦略 2009 によると、2008 年度の TH 区にお ける区立図書館利用率は住民全体の 56\%に至った注 4)。また TH 区 の 2014 年の年次住民調査によると、抽出された調査対象住民の 61\% が区立図書館のサービスに対して高い評価を示している注 5)。
(人)

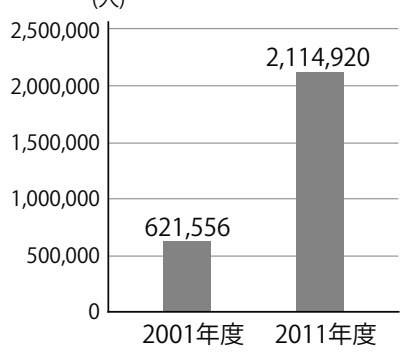

TH区の年間訪問者数

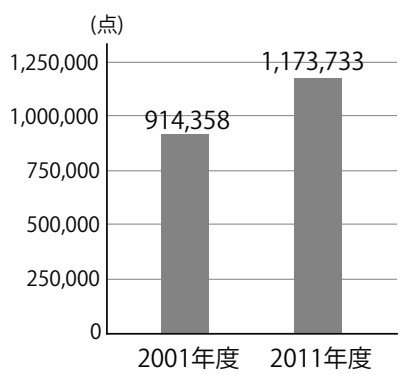

TH区の年間貸出数

図 3 IS 開館前後の TH 区の公共図書館利用の比較

表 5 公共図書館計画に関する政策

\begin{tabular}{|c|c|}
\hline 策定機関 & 政策 \\
\hline $\begin{array}{c}\text { Department for } \\
\text { Culture, } \\
\text { Media and } \\
\text { Sport }\end{array}$ & \begin{tabular}{|l|} 
- Reading the Future (1997/2) \\
- Annual library Plan (1998) \\
- Comprehensive, Efficent and modern public libraries: Standards and Assessment (2001) \\
- Framework for the Future: libraries and information in the next decade (2003/2) \\
- The modernisation review of public libraries (2010/5)
\end{tabular} \\
\hline \begin{tabular}{|c|} 
Museums, \\
Libraries and \\
Archives Coucil
\end{tabular} & $\begin{array}{l}\text { - New library: The people's Network (1997) } \\
\text {-Public Libraries Archives and New Development: A Standard Charge Approach (2010/3) } \\
\text { - Universal Offer (2013) }\end{array}$ \\
\hline
\end{tabular}

Archives Coucil • Universal Offer (2013)

\begin{tabular}{|c|ll|}
\multicolumn{1}{l}{ 表 6 公共サービスの展開に関する政策及び事業 } \\
\hline 策定機関 & \multicolumn{2}{|c|}{ 政策 } \\
\hline 多機関 & •Making Health Choices Easier(2004) & •Skilled for Health Programme (2009) \\
\hline
\end{tabular}

\begin{tabular}{|c|c|}
\hline 策定機関 & 政策 \\
\hline $\begin{array}{l}\text { Greater London } \\
\text { Authority }\end{array}$ & - London Plan(2004, 2008修正, 2011修正) \\
\hline $\begin{array}{c}\text { Tower Hamlets } \\
\text { Council }\end{array}$ & $\begin{array}{l}\text { - Tower Hamlets Community Plan to } 2010 \text { (2001) } \\
\text { - Tower Centre Spatial Strategy to } 2025 \text { (2009/7) } \\
\text { - Infrastructure delivery Plan (2009/9) } \\
\text { - Tower Hamlets Community Plan to } 2020 \text { (2008 草案, 2011/4最終版) } \\
\text { - Core Strategy Development Plan Document to } 2025 \text { (2010/9) } \\
\text { - Managing Development Document (2013/4) }\end{array}$ \\
\hline
\end{tabular}

このような変化から、TH 区立図書館の再編は一定の成果を収め ていると評価できる。そこで、次章からは、この再編の背景にある イギリスの公共図書館に関する政策や、ロンドン及び TH 区の都市・ 地域計画に関する政策に着目し、IS との関係を分析する。

\subsection{5 の整備に関わる政策}

\section{4-1. イギリス及びロンドンの公共図書館行政}

イギリスには中央政府 (Central Government) と、地方政府 (Local Government) の二段階の政権が存在するが、公共図書館行政を所管 するのは中央政府の文化・メディア・スポーツ省 (Department for Culture, Media and Sport、以下 DCMS) であり、ロンドンではロン ドン特別区が担当する。

\section{4-2.IS の整備に関係する政策及び事業の分類}

IS 戦略 2009 によると、IS の整備には多くの政策や事業内容が 関連しているが、それらを分析した結果、以下の 3 つに分類する ことができる。

(1)公共図書館計画に関する政策 (表 5)

(2)公共サービスの展開に関する政策および事業 (表 6)

(3)都市・地域計画に関する政策 (表 7)

そして、これらの政策を時系列的に整理したものが図 4 である。 次章からは図 4 を基に各種政策と IS の関係について分析する。

5. イギリスの公共図書館計画に関する政策と IS の関係

イギリスでは 1980 年から全国的に公共図書館の利用率が低下 


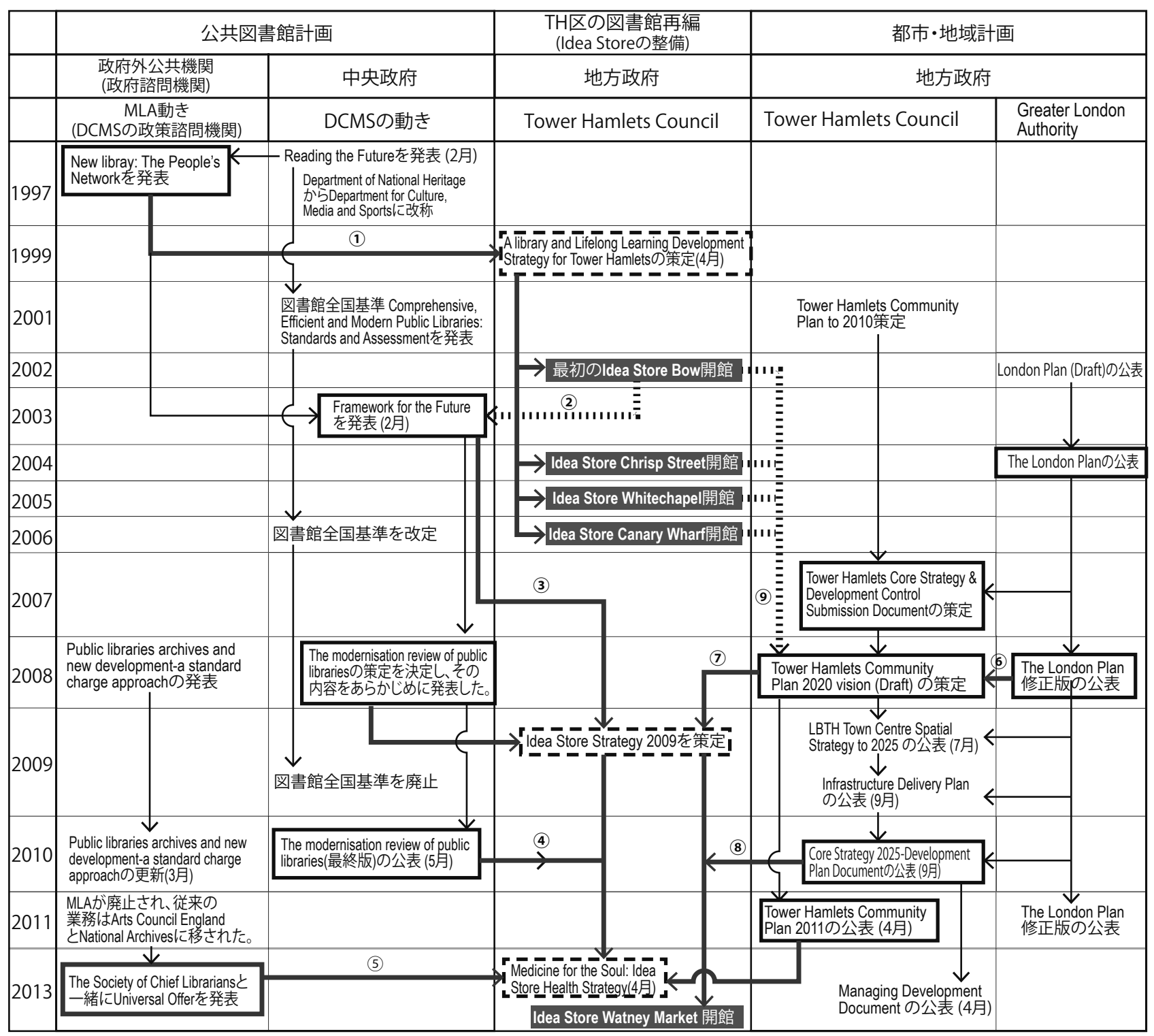

(1) The People's Networkの公表は、中央政府がITサービスの普及に取り組む出発点になり、IS戦略1999はITサービスの提供を図書館サービスの中心の1つにした。

(2)「Framework for the Future」の中でISの建築的な空間整備と学習プログラムの提供などは、今後の公共図書館再編において参考すべき事例として紹介された。

(3) 読書と非公式学習の促進、デジタル・サービスの向上、地域ニーズへの対応という3つをテーマにした「Framwork for the Future」の内容に基づき、IS戦略2009は「 読書、校外学習の提供」「健康支援サービスの提供」「就業支援サービスの提供」「地域コミュニティの結束の強化」をTH区立図書館の果たすべき役割とした。

(4)「The modernisation review of public libraries」が示した21世紀の公共図書館の革新に向けた54項目の内の1つが健康支援サービスである。

(5)「Universal Offer」により発表された公共図書館の共通サービスの1つが健康支援サービスであり、これはISの健康支援戦略書である「Medicine for the Soul: Idea Store Health Strategy」の策定を促した。

(6) ロンドン・プランはTown Centreをベースに公共サービスを提供するThe London Town Centre Networkを提案し、IS戦略2009はロンドン・プランに基づいて Town Centrek図書館を配置する方針も示した。

(7) TH区のコミュニティ・プランはLondon PlanとTH区のLDFに基づき、TH区内のTown Centreに公共サービスを充実させる計画を示した。また、「IS戦略2009」は TH区のコミュニティ・プランで指摘された地域課題である就業支援と健康支援に対し、ISで就業に必要な学習プログラムと健康に関する情報を提供する方針を 示した。

8) Core Strategy 2025は、Town Centreに公共施設を集中させるTH区のコミュニティプランに基づいて、5番目のISを整備する方針を示した。

(9) コミュニティ・プランはISが提供する学習プログラムを高く評価し、その後もISで地域課題に応じた就業と健康支援の学習プログラムを展開する方針を示した。 凡例

$$
\begin{aligned}
& \longrightarrow \text { 政策および事業の関連 } \\
& \text { II!I!I!) ISからの示唆 }
\end{aligned}
$$

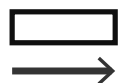

ISの整備に大きな影響を与えた政策 ISに再編した背景、間接的要因 r-ーー】 Idea Storeの戦略

Idea Storeの開館

図 4 関連政策及び事業と IS の相互関係 (1997～2013)

したため、DCMS は公共図書館の復興を目指して、中央政府の公 共図書館ビジョンとして 3 つの政策を順次策定した。具体的には、 $\left\lceil\right.$ Reading the Future ${ }^{14)}(1997) 、 「$ Framework for the Future $」$ 15) (2003)、「The modernisation review of public libraries」 ${ }^{16)}$ (2010) である。この 3 つの政策を中心に、イギリスの公共図書館政策の
変遷と IS の関係を分析する。

5-1.Reading the Future

DCMS の前身である Department of National Heritage(DNH) は 1997 年に中央政府としての最初の公共図書館ビジョンとなる 「Reading the Future」を発表し、公共図書館における IT サービス 
の充実、成人学習の支援などを強調した。また同年には、DCMS の政策諮問機関である図書館情報委員会 (Library and Information Commission: 2000 年に Museums, Libraries and Archives Council として統合。以下 MLA) が「新しい図書館一市民のネットワーク」

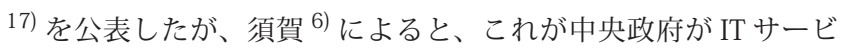
スの普及に取り組む出発点になった (図 4 中の(1))。さらに、2001 年に発表された公共図書館の「全国基準」18)においては、公共図 書館におけるインターネットにアクセスできるコンピューターの整 備台数などの目標值が提示された。このように、公共図書館におけ る IT サービスの普及に向けた制度の整備が進む中で、TH 区が策定 した IS 戦略 1999 は、IT サービスの提供と生涯学習支援を TH 区 立図書館サービスの中心に位置づけた。

\section{5-2.Framework for the Future}

2003 年に DCMS は中央政府の 2 番目の公共図書館ビジョンと して「Framework for the Future」を発表した。この政策では、(1) 読書と非公式学習注6) の促進、(2)デジタル・サービスの向上、(3)地 域ニーズへの対応を今後の公共図書館が担うべき使命とした。また、 その中で、IS は公共図書館再編の先進事例として紹介され、TH区 による区立図書館の再配置や地域課題に対応した学習プログラムの 導入などは、公共図書館の有効な再編方法として評価された (図 4 中の(2)。

これを受けて、IS 戦略 2009 では「Framework for the Future」 に提示された公共図書館サービスを基に、今後の TH 区立図書館に おいて(1)読書、学校外での学習、IT サービスの提供、(2)健康支援サー ビスの提供、(3)就業支援サービスの提供、(4)地域コミュニティの結 束の強化への貢献に積極的に取り組む方針が示された。(図 4 中の (3) $)$

一方、「全国基準」は 2009 年に廃止され、DCMS は 3 番目の 公共図書館ビジョンとなる「The Modernisation Review of Public Libraries」の草案を 2008 年に発表し、2010 年に最終版を公表した。 5-3.The modernisation review of public libraries

これは「Framework for the Future」に基づきながら、その内容 をさらに充実させたものであり、公共図書館の6つの目標を示した。 具体的には(1)図書館サービスの質の向上、(2)図書館利用の復興、(3) 公共サービスの集約と資金収集、(4)開館時間の延長、(5) IT サービ スの充実、(6)他の公共機関と連携した図書館サービスの提供注 7) か らなる。そこでTH 区は、2008 年に発表されたこの草案の内容を 盛り込んで、新たな公共図書館サービスを展開する IS 戦略 2009 を策定した。

これに並行して、2008 年に MLA は「Public Librareis, Archives and New Development: A Standard Charge Apporach」19) を発表し た。ここでは公共図書館の必要空間、標準面積や建設費用等が詳し く示されていたが、施行上、強制的な基準ではなく、MLA は地域 の事情に合わせた図書館づくりを勧めた。

\section{6. 公共サービスの展開に関する政策及び事業とIS の関係}

公共図書館に関する行政機関だけではなく、医療や保健を所管す る行政機関も公共図書館のもつ健康の維持や増進に関わる情報の発 信力に注目している。

2004 年にイギリスの保健省 (Department of Health) は「Crossing

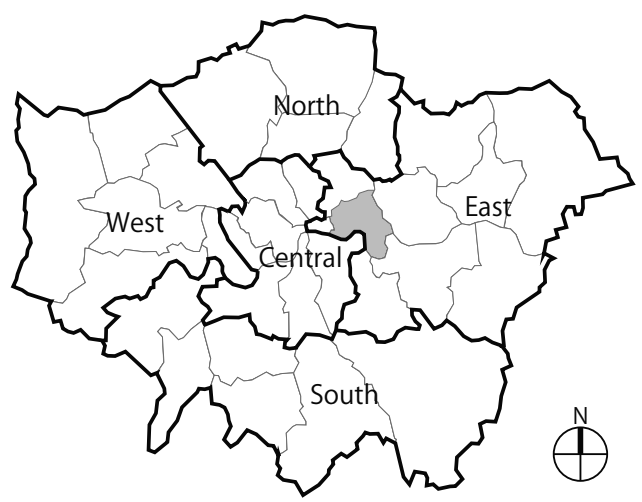

凡例 :

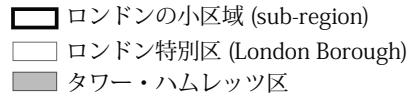

図 5 2004-2008 年のロンドンの小区域とロンドン特別区

表 $8 \quad 2001-2016$ 年のロンドン小区域の発展予測

\begin{tabular}{|c|c|c|c|c|c|c|c|}
\hline \multirow[b]{2}{*}{ 小区域 } & \multicolumn{3}{|c|}{ 人口 } & \multirow{2}{*}{\begin{tabular}{|c|} 
住宅 \\
毎年増加 \\
最低目標値 \\
(千示)
\end{tabular}} & \multicolumn{3}{|c|}{ 就業者 } \\
\hline & $\begin{array}{c}2001 \text { 年 } \\
\text { (千人) }\end{array}$ & $\begin{array}{c}2016 \text { 年 } \\
\text { (千人) }\end{array}$ & $\begin{array}{l}\text { 毎年増加数 } \\
\text { (千人) }\end{array}$ & & $\begin{array}{c}2001 \text { 年 } \\
\text { (千人) }\end{array}$ & $\begin{array}{c}2016 \text { 年 } \\
\text { (千人) }\end{array}$ & $\begin{array}{c}\text { 毎年増加数 } \\
\text { (千人) }\end{array}$ \\
\hline Central & 1525 & 1738 & 14.2 & 7.1 & 1644 & 1883 & 15.9 \\
\hline East & 1991 & 2262 & 18.1 & 6.9 & 1087 & 1336 & 16.6 \\
\hline West & 1421 & 1560 & 9.3 & 3.0 & 780 & 866 & 5.7 \\
\hline North & 1042 & 1199 & 9.0 & 3.1 & 386 & 412 & 1.7 \\
\hline South & 1329 & 1380 & 3.4 & 2.8 & 587 & 623 & 2.4 \\
\hline
\end{tabular}

注 ）この表は London Plan 2004, p.224 を基に作成。

Health: Making Health Choices Easier」20) を策定したが、その中 で公共図書館は健康を維持するための重要な情報発信源として位置 づけられた。また、Skilled for Health Programme 注 ${ }^{8)}$ に基づいて、 MLA は先行的に 5 つのロンドン特別区注 9) の区立図書館において 健康に関する学習コースを提供した。このような背景の中で、IS 戦略 2009 でも健康支援に関する情報提供に対する IS の可能性を さらに追究する方針が盛り込まれた。

健康支援に関しては、5-3で述べた「The modernisation review of public libraries」においても、21 世紀の望ましい公共図書館サー ビスとして示された 54 項目の 1 つが健康支援サービスであった (図 4 中の (4))。MLA は 2011 年に解散し、従来の業務は Arts Council England と National Archivesに移されたが、Arts Council England は2013 年に The Society of Chief Librarians および The Reading Agency とともに Universal Offer を発表し、(1)読書、(2)情報提供、 (3)デジタル提供、(4)健康支援の 4 つを今後の公共図書館の共通提 供サービスとして定義した。このような一連の動きが、2013 年の IS の健康支援戦略である「Medicine for the Soul: Idea Store Health Strategy」 21)の策定を促すことになった（図 4 中の(5)）。

\section{7. 都市・地域計画に関する政策と IS の関係}

公共図書館計画の関連政策とともに、IS はロンドン及び TH 区の 都市・地域計画にも梁く関連している。そこで、最も重要と考えら れる 3 つの政策を取り上げて、特に IS の配置に関する状況および 計画との関連性を分析する。

7-1. ロンドン・プラン (The London Plan) とIS の関係

ロンドン・プラン ${ }^{22)}$ は大ロンドン行政 (Greater London Authority) がロンドンの今後 $15 \sim 20$ 年間の都市計画の方針を 
示した政策である。最初のロンドン・プランは 2004 年に公表さ れ、2008 年と 2011 年に改正された。現在のロンドン・プランは 2031 年までを対象期間としている。本稿では IS 戦略 2009 に影響 を与えた 2004 年のロンドン・プランの内容と IS の配置に関する 状況および計画の関係について分析する。

ロンドン・プランはロンドンの居住、就労、交通、自然などにつ いて、様々な都市スケールの整備計画を提示し、さらに図 5 に示 すロンドンの 5 つの小域 (sub-region) における実施方法を示し た。ロンドン・プランによると、ロンドン小区域の今後の発展予測 は表 8 の通りであるが、2001 年から 2016 年までの間に TH 区を 含めた East 小区域が最も発展すると予想されており、それを支え る都市インフラの整備が必要になるとしている。

また、ロンドン・プランでは今後発展が見込まれるエリア が Opportunity Area注 10) として指定されている。TH区では Whitechapel と Isle of Dogs (Canary Wharf を含む) が指定されて いるが (図 6)、現在 Whitechapel に立地する ISW は IS の旗艦的 な位置付けがされており、最も充実した学習プログラムを提供し ている。一方、Canary Wharfに位置するISCW はビジネス・エ リアに立地した特性を活かしながら、主に英語学習コースを介し た就業支援を行っている(表 4)。このことから、TH区の2つの Opportunity Area に立地している ISW と ISCW ではロンドン・プ ランの方針を反映したプログラムが提供されていると考えられる。

\section{7-2. Town Centre Network と IS の関係}

さらに、ロンドン・プランでは The London Town Centre Network が提案され、現在の Town Centre をべースに公共サービ スを提供する地域拠点ネットワークの構築を各ロンドン特別区に 求めている。具体的には、Town Centre に積極的に商店や住宅、職 場、公共施設を立地させ、持続的な発展を求めている。現在、5 IS と既存の BGL 及び CTL はすべて TH 区の Town Centre 注 11) に立 地している。

IS の配置計画については、ロンドン・プランが策定される前の IS 戦略 1999 において、地域住民が日常的に利用する商業施設と 近い場所に IS を配置させることを既に決定しており、4 つの IS は この方針に基づいて開館した。しかし、2009 年の TH 区のインフ ラ整備計画書である「Infrastructure Delivery Plan」23) と IS 戦略 2009 においては、5 番目の IS をどこに配置するかはまだ決定し ておらず、Town Centre に公共施設を集中させる TH 区の地域計画 (7-4 で詳述する Tower Hamlets Local Development Framework) な どに基づきながら決定する方針が示された (図 4 中の6)。実際に、 5 番目の IS である ISWM はこの方針に基づいて、2013 年に Town Centre であるWatney Market に開館した (図 6)。

7-3.Tower Hamlets Community Plan と IS の関係

コミュニティ・プランはイギリスの地方政府が地域の経済や、環 境、社会の改善に関する今後 10 年の発展方針を示した計画書であ り、イギリスの全ての地方政府に策定義務がある。また、ロンドン の各特別区がコミュニティ・プランを策定するにあたっては、前述 したロンドン・プランの内容が重要な指針になる。

TH 区 2001 年に「Tower Hamlets Community Plan( 以下、 THCP) to 2010」 24) を策定したが、2008 年には次の 10 年の計画 の草稿である「THCP 2020 Vision」 25) を公表し、2011 年にはそ

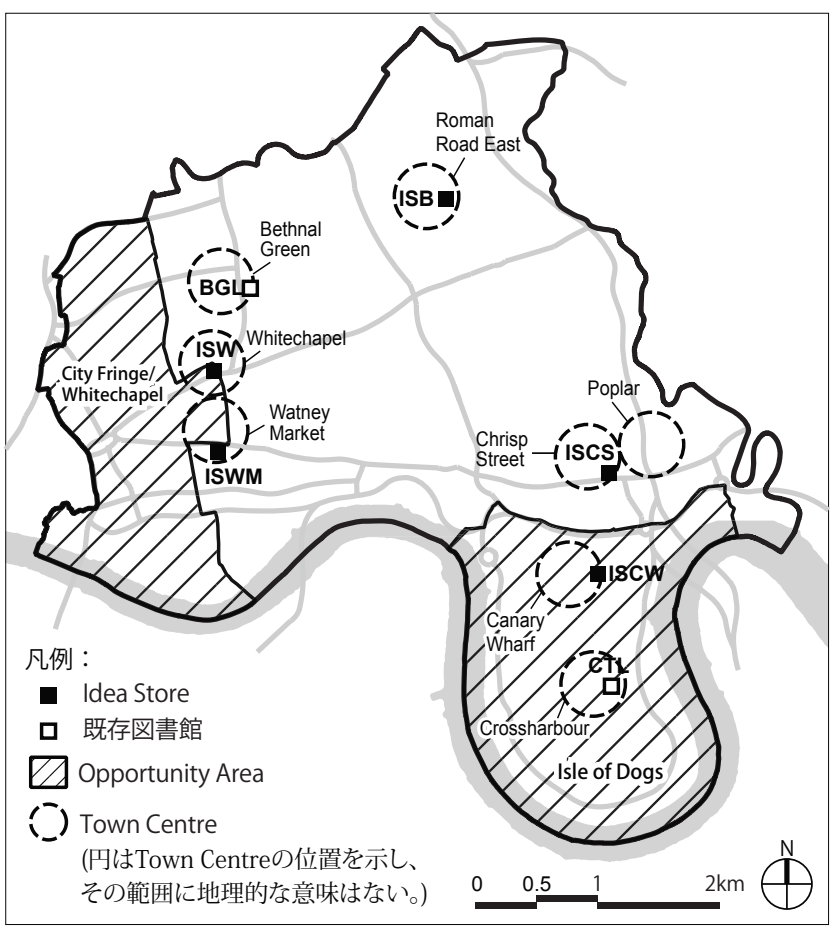

図 6 TH 区の Town Centre と Opportunity Area と IS の配置

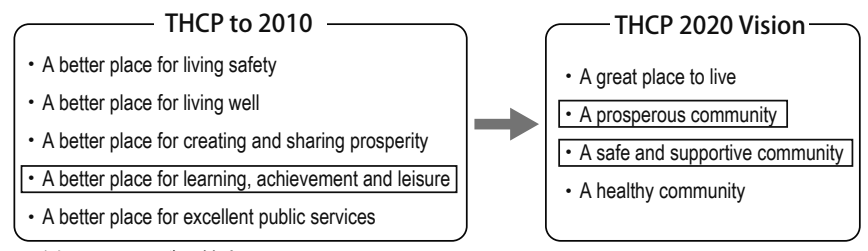

凡例： $\square$ IS が貢献する項目

図 7 TH 区のコミュニティ・プランが示した IS の役割の変化

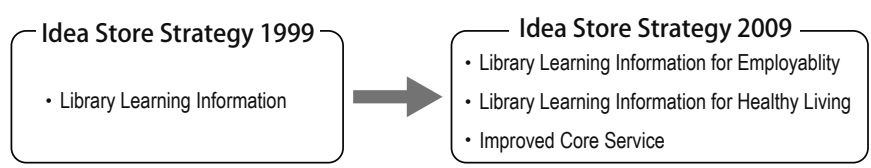

図 8 IS 戦略における提供サービスの変化

の最終版である「THCP 2011」26) を公表した。図 7 は「THCP to 2010」と IS 戦略 2009 に影響を与えた「THCP 2020 Vision」の 戦略テーマとその変化をまとめたものである。

「THCP to 2010」では IS をレジャー施設としても位置づけ、住 民に余暇時間を過ごせる場所として図書館を提供し、さらに生涯学 習プログラムを図書館に導入する戦略を示した。しかし、「THCP 2020 Vision」では、IS の学習プログラムを通じて地域雇用を改善 し、さらに情報発信による健康支援を行う方針が確認できる。つま り、TH 区のコミュニティ・プランから読み取れる IS の役割につい ては、当初の生涯学習支援に就業・健康支援が加味されたと言える (図 7)。これはIS 戦略 1999年とIS 戦略2009 が示したIS の提供サー ビスの変化とも一致している (図 4 中の (7)、図 8)。

7-4. Tower Hamlets Local Development Framework と IS の関係

TH 区のコミュニティ・プランに基づいて策定された地域計画が Local Development Framework(以下LDF)である。このLDF は「Core Strategy 2025 - Development Plan Document(以下、Core Strategy 2025)」27) と「Managing Development Document」 ${ }^{28)}$ の 2 つ 
政策から構成される。

「Core Strategy 2025」はLDF の中の主要な政策である。2010 年 9 月に公表された「Core Strategy 2025」は居住環境の向上、就 業・学習支援、交通改善を向けた TH 区のマスタープランを提示 し、ロンドン・プランが求める Town Centre ネットワークの構築 を実現していく方策を示した (図 4 中の 8) )。一方、「Managing Development Document」は「Core Strategy 2025」を構成する住宅、 オフィス、公共施設の配置計画や各選挙区 (ward) ごとの発展方針 を具体的に示している。

この 2 つの政策は、TH 区の公共施設全般の配置に対して影響を 与えるものであり、IS の配置計画においても極めて重要な政策だと 考えられる。実際に、7-2で述べたように ISWM はロンドン・プラ ンをはじめとする一連の都市・地域計画の政策に基づいて、Town Centre に配置された。

さらに、2009 年には「Core Strategy 2025」に基づいた「Town Centre Spatial Strategy to 2025」29) が公表され、TH 区の各 Town Centre について、それぞれの地域特性の分析を踏まえた整備計画 が示された。この計画は今後の IS の開設や IS と他の公共施設との 連携構築などに大きな影響を与えるものとして考えられる。

\section{7-5. 関連政策と IS の整備の相互関係}

6 章での分析とともに、TH 区立図書館は主に次の 3 つの考え方 に従って再編され、地域再生の拠点として位置づけされていること が分かる。

(1)中央政府の公共図書館に関する政策に基づいて、IT サービスを 充実し、さらに生涯学習、健康支援などを TH 区立図書館サービ スに導入したこと。

(2)このように再編された図書館サービスを多くの住民が享受できる ように、都市・地域計画の政策と連携しながら TH 区立図書館を 再配置したこと。

(3)さらに、IS の取り組みや成果は公共図書館政策と都市・地域計 画にフィードバックされ (図 4 中の(2)(9))、それが加味された新 たな政策がその後の IS の整備に影響を与えたこと。

つまり、これまでの TH 区立図書館の再編としての IS の整備は、 地域の課題とニーズに対応した政策と実空間の計画・整備がスパイ ラル・アップの構築プロセスとして展開されてきたと見ることがで きる。

\section{8. 総括}

(1)「Reading the Future」や「Framework for the Future」などの イギリスの中央政府から提示された新しい公共図書館のビジョ ンは、IS の整備において重要な方向性を示した。IS はこの各種 の公共図書館政策に基づいて、住民が必要とする情報を発信す る公共図書館機能を基盤にしながら、図書やインターネットに よる情報発信と学習コースの提供などを通じて、就業支援や健 康支援も実施している。その結果、この 12 年間で TH 区の半分 以上の住民が IS を含む TH 区立図書館を利用するようになり、 同時に利用者満足度を向上させるなどの成果を上げた。これは、 全ての住民に開かれているという公共図書館の空間・機能の基 本特性を活かしながら、地域課題に対応して必要となる公共サー ビスを新しく内包していくこれからの公共図書館の空間と運営
の再編の方向性を例示している。

(2) IS の整備に際しては、TH 区は図書館の数よりも、その内容の 質やアクセスしやすい立地を重視し、複数の TH 区立図書館の 配置を総合的に検討し、再配置を実施した。特に、商業施設や 公共交通拠点に隣接するように再配置することにより、図書館 利用が住民の日常生活の一部になることを目標とし、実現した。 さらに、ロンドン・プランと「THCP to 2020」の公表以降には、 Town Centre のネットワーク構築を核とした新しい都市・地域 計画に即した区立図書館の再配置を計画し、実施している。

(3)このように、TH 区は公共図書館に関する行政計画だけではな く、母都市の上位計画に基づいて TH 区立図書館の再配置を実施 し、さらに地域課題の解決を目指すコミュニティ・プランと連 動しながら区立図書館として新たなプログラムを提供すること によって、地域の課題とニーズに対応した区立図書館の再編を 実現した。これは、今後の日本の公共施設の再編において必要 になってくる施設の再配置や新たなプログラムの開発とそれに 応じた建築空間の計画において、都市・地域計画と公共施設の 再編が連動する必要性と重要性を示唆している。

(4)本稿の考察から、都市・地域計画および関連政策と IS の配置計 画および提供プログラムの関係が明らかになったが、本稿で指 摘した IS の立地性とともに 1-2 で述べた建築空間及び提供プロ グラムの関係をより具体的に分析することにより、TH 区立図書 館の再編の評価や意義を明らかにし、日本の住民・市民の生活 の質を維持、向上させるための実効的な公共施設再編に向けた 知見を得ることが必要である。これは次の研究課題として別稿 で改めて論じたい。

注

注 1) 日本の公共施設の再配置に関する政策として「都市再生特別措置法に 基づく立地適正化計画制度」が確認できるが、公共図書館の施設整備に 特化した政策ではない。

注 2) イギリスのCIPFA(Chartered Institute of Public Finance and Accountancy) が 2014 年 12 月 11 日に公表した CIPFA Libray Survey 参照した。

注 3) IS 戦略 1999 では、TH 区の既存図書館は数的には充実しているが、そ の多くは住民がアクセスしにくい場所に立地しているため、利用率がと ても低くなっていることが指摘された。この課題認識については、2014 年の 2 月に筆者が実施したヒアリング調査でも確認された。

注 4) IS 戦略 2009 で引用されている 2009 年に公表されたイギリスの各公 共サービスを評価する全国評価指標 (National Indicators) における公共 図書館利用の評価指標 (NI9) のデータを参照した。

注 5) 2014 年に行われた TH 区の年次住民調査によると、TH 区の住民から 抽出された 1147 人の調査対象の $61 \%$ が TH 区の区立図書館サービスを 「良い」「とても良い」「非常に優れている」のいずれかで評価していた。

注 6) イギリスの非公式学習 (Informal Learning) は、雇用や資格、学位の取 得に直接結びつかないが、個人の充足や市民参加、コミュニティの発展 を目指して主に個人の行動によって行われる学習として位置付けされて いる。

注 7)「The modernisation review of public library」において、図書館の重 要性と不可欠性を市民や政治家に表明するためには、他の公共サービス と連携しながら、住民の教養向上や健康維持などの地域課題に貢献する ことを目指すべきだとの主張が記された。

注 8) 社会的弱者に向けた健康支援プログラムであり、食事会や運動などの 活動を通して、健康を維持するための教育が行われた。資金は、イギリ 又保健省 (Department of Health) とイノベーション、大学、職業技能省 
(Department of Innovation, Universities and Skills) から提供された。

注 9) 各々は Barking、Dagenham、Ealing、Newham Islington、Haringey の 5 特別区である。

注 10) ロンドン・プラン (2004) では、大量な新入居者と就職者を収容し、 大規模な発展が期待できるエリア (5000 種以上の職、2500 戸以上の住 戸を提供し、便利な公共交通機関を整備した場所 ) が Opportunity Area として定義された。

注 11) 2004 年のロンドン・プランで指定された TH 区の Town Centre は (1) Bethnal Green、 (2) Chrisp Street、 (3) Polar、 (4) Whitechapel、(5) Roman Road East、(6) Watney Market、(7) Canary Wharf の 7 つであり、 2008 年のロンドン・プランでは Crossharbour も追加された。

\section{参考文献}

1）荒井広明：新構想図書館「アイデアストア」（ロンドン・タワーハムレッ ツ区）の 10 年, http://ameblo.jp/booksharing/day-20130715.html を参 照 [2013.10.18 9:11 確認 ]

2）関直規：ロンドンにおけるコミュニティ教育施設の戦略・発展と成果 タワー・ハムレッツ区の「アイディア・ストア」の事例, 日本公民館学 会年報,第 10 号,pp.116-124, 2013

3) 須賀千絵 : 英国公共図書館訪問記 3( タワー・ハムレット), みんなの図書 館 (312), pp.51-62, 2003

4) アントネッラ・アンニョリ：知の広場一図書館と自由, みずず書房, 2011.5

5) Jo Hartley: Tower Hamlets 'Idea Store: Are They Working, A Study Submitted in Partial Fulfillment of the Requirements for the Degree of Master of Arts in Librarianship at the University of Sheffield, 2005.9

6）須賀千絵：英国の公共図書館・博物館法と中央政府の役割の変容, 情報 の科学と技術,第 59 巻,第 12 号,pp.579-584, 2009.12

7) CIPFA Library Survey, http://www.ons.gov.uk/ons/rel/pop-estimate/ population-estimates-for-uk--england-and-wales--scotland-and-northernireland/index.html [2014.12.21, 19:42 確認 ]

8）日本図書館協会図書館調査事業委員会：日本の図書館一統計と名簿 2013, 日本図書館協会, 2014.1

9) 市町村要覧編集委員会:日本の図書館一統全国市町村要覧 (平成 24 年版), 第一法規株式会社, 2012.10

10) Population Estimates for UK, England and Wales, Scotland and Northern Ireland - Mid-2013, http://www.cipfa.org/about-cipfa/press-office/latestpress-releases/cipfa-library-survey\# を参照 [2014.12.21, 17:26 確認 ]

11) Population Estimates for UK, England and Wales, Scotland and Northern Ireland - Mid-2011 and Mid-2012, http://www.ons.gov.uk/ons/rel/popestimate/population-estimates-for-uk--england-and-wales--scotland-andnorthern-ireland/index.html [2014.12.21, 19:21 確認]

12) Tower Hamlets Council: A library and Lifelong Learning Development Stategy for Tower Hamelts, 1999.4

13) Tower Hamelts Council: Idea Store Strategy 2009, 2009

14) Department of National Heritage: Reading the Future, 1997.2

15) Department for Culture, Media and Sport: Framework for the future 2003.2, http://www.healthlinklibraries.co.uk/pdf/Framework_for_the_ Futures.pdf [2014.4.28 11:05 確認]

16) Department for Culture, Media and Sport: The modernisation review of public libraries: a policy statement, 2010.3, https://www.gov.uk/ government/publications/the-modernisation-review-of-public-libraries-apolicy-statement を参照 [2014.4.23 19:14 確認]

17）英国図書館情報委員会 著,永田治樹と他 3 名 訳 : 新しい図書館 - 市民 のネットワーク, 日本図書館協会, 2001.7

18)Department of Cuture, Media and Sport: Comprehensive, Efficient and Modern Public Libraries - Standards and Assessment, 2001

19)Museums, Libraries and Archives: Public Libraries, Arhicves and New Development-A standard Charge Approach, 2010

20)Department of Health: Chossing Health-Mkaing Health Choices Eaasier 2011.04, http://www.smokefreeengland.co.uk/files/choosing-health.pdf [2014.9.21 18:44 確認]

21)Tower Hamelts Council: Medicine for the Soul-Idea Store Health Strategy, 2013

22)Greater London Authority: The London Plan, 2004.2

23)Tower Hamlets Council: Tower Hamlets Infrastructure Delivery Plan,
2009.09

24)Tower Hamlets Partnership: The Community Plan 2007-2008 (The Community Plan to 2010), 2007, http://modgov.towerhamlets.gov.uk/ Published/C00000320/M00002004/AI00010067/\$CommunityPlanAp px1060607.docA.ps.pdf [2014.6.25 15:15 確認]

25)Tower Hamlets Partnership: Tower Hamlets Community Plan 2020 vision, 2008

26)Tower Hamlets Partnership: Tower Hamlets Community Plan 2011, 2004.11

27) Tower Hamlets Council: Core Stategy 2025-Development Plan Document, 2010.09

28)Tower Hamlets Council: Managing Development Document-Development Plan Document, 2013.04

29)Tower Hamlets Council: London Borough Tower Hamlets Town Centre Spatial Strategy to 2025, 2009.7

30) 李燕、小松尚：ロンドンの Idea Store に見る地域ニーズに対応した公共 図書館の再編方法, 日本建築学会大会学術講演梗概集,E-1, pp. 893-894 2014 


\title{
RELATIONS BETWEEN URBAN PLANNING AND REORGANIZATION OF PUBLIC LIBRARY 'IDEA STORE' IN LONDON, CORRESPONDING TO THE LOCAL PROBLEMS AND NEEDS
}

\author{
Yan LI* and Hisashi KOMATSU** \\ * Research Institute of Architecture, M.Arch. \\ ** Assoc. Prof., Graduate School of Environmental Studies, Nagoya University, Dr. Eng.
}

In Japan, there's few policies showing the direction of reorganization of public library, especially of arrangement of library's space and programme. Therefore, the purpose of this study is to clarify the progress of reorganization of public library 'Idea Store' in Tower Hamlets, London, which has been successfully renewed to correspond to the local problems and needs. This research focuses on UK library policies, London spatial plan and Tower Hamlets's community plan, and aims to make clear of relations between these policies and reorganization of Idea Store.

Tower Hamlets is one of the most deprived London Boroughs in London with high levels of unemployment, particularly among the ethnic minorities. Besides, the quality of public services in borough was very low, especially public library service. In 1990s, there were 13 public libraries in Tower Hamlets, but most of them were very bad at performance because of their bad location. In the result, Tower Hamlets Council decided to reorganize local public libraries from 13 to 7, and renewed them as 'Idea Stores' by launching 'Idea Store Strategy'. The renewed libraries, named as Idea Stores, are located at the heart of Tower Hamlets's local shopping centre, besides the underground stations which is very easy to access and to combine a visit to library with other activities, particularly shopping. In Idea Store, there is not only reading spaces, but also cafe, learning classrooms, One Stop Shops and children's library. There are 5 Idea Stores and 2 existing libraries in Tower Hamlets so far.

Tower Hamlets launched the first Idea Store Strategy in 1999. In 'Idea Store Strategy 1999', it was decided to offer a wide range of adult learning classes in Idea Store as well as the traditional library service. Besides, in 'Idea Store Strategy 2009' which was launched in 2009, it was decided to expand the learning service offer with more emphasis on employability and healthy living. In fact, there are 3 types of policies that provide the context for improving the Idea Store Strategy. They are the policies relating to the public library services, the policies relating to the wider public services and the policies relating to the London's urban planing and Tower hamlet's community plan.

Regarding the policies relating to the public library service, there are 3 policies showing the government's vision for the future's public library services. These policies are 'Reading the Future', 'Framework for the Future' and 'the Modernisation review of public libraries'. According to these policies, Tower Hamlets imported IT and learning services into Idea Stores. Moreover, it concentrated on public libraries's support in borough's informal learning, heath, employability and community cohesion.

Regarding the policies relating to the spatial planning of London and Tower Hamlets, 'London Plan' and 'Tower Hamlets Community Plan' provided important content to improve Idea Store. Tower Hamlets Council relocated the libraries to enhance the building of the The London Town Centre Network proposed in London Plan. Besides, it expanded library service to support borough's employability and healthy life according to the Tower Hamlets's Community Plan.

In conclusion, Tower Hamlets renewed local libraries not only according to the polices relating to the public library services, but also according to the policies relating to the London's urban planning and Tower Hamlets's community plan. And it is because of this cooperation between reorganization of public libraries and urban planning, that Idea Store can correspond to the Tower Hamlets' local problems and needs. 